F. Reprod. Fert. (1970) 22, 253-260

\title{
USE OF A CONTINUOUS FLOW DIALYSIS APPARATUS TO DETERMINE THE EFFECT OF CATIONS, BUFFERS AND OSMOTIC PRESSURE ON RAM SPERMATOZOA
}

\author{
P. J. QUINN, I. G. WHITE AND J. K. VOGLMAYR \\ Department of Veterinary Physiology, University of Sydney, \\ Sydney, Australia
}

(Received 24th May 1969, revised 23rd fuly 1969)

\begin{abstract}
Summary. When ram semen was dialysed against phosphate-glucose diluents with a cation composition similar to rete testis fluid, epididymal and ejaculated seminal plasma and ejaculated ram spermatozoa, the impedance change frequency (ICF) was maintained best over $6 \mathrm{hr}$ in the latter diluent. Krebs-Ringer-glucose buffered with sodium phosphate or trisodium citrate maintained the ICF at a high level, whereas tris- $\mathrm{HGl}$ and veronal-HGl buffers caused a rapid decline in ICF. Hypertonic dialysis media severely depressed the IGF within $1 \mathrm{hr}$, whereas hypotonic diluents gave results similar to Krebs-Ringer-phosphate.

Adding $1 \mathrm{~mm}$-calcium or 5 to $51 \mathrm{~mm}$-potassium to an isotonic dialysis fluid was beneficial and the effects on ICF were additive. The omission of potassium from the hypotonic diluent caused no significant reduction in ICF.
\end{abstract}

\section{INTRODUCTION}

As fluid passes from the testis to the cauda epididymidis of the ram and bull, the sodium concentration decreases (Gragle, Salisbury \& Muntz, 1958; Scott, Wales, Wallace \& White, 1963; Crabo \& Gustafsson, 1964; Wales, Wallace $\&$ White, 1966) and rises slightly again on admixture with the accessory secretion at ejaculation (Gragle et al., 1958; Quinn, White \& Wirrick, 1965). The ratio of potassium to sodium in the lumen fluid tends to be greater, therefore, in the cauda epididymidis than in rete testis fluid or ejaculated seminal plasma and this has been suggested as a possible explanation for the quiescence of spermatozoa in the epididymis of the bull (Salisbury \& Cragle, 1956; Sørensen \& Andersen, 1956; Salisbury, 1962; Crabo, 1965). The continuous flow dialysis apparatus (CFDA) has been used in the present study to determine the effect of dialysis against diluents of cation compositions similar to rete testis fluid, epididymal and ejaculated seminal plasma and ejaculated spermatozoa. Dialysis against Krebs-Ringer has been made for comparison.

Very high potassium concentrations decrease the motility (White, 1953) and metabolism (Cragle \& Salisbury, 1959) of spermatozoa and the latter authors 
found that high concentrations of calcium stimulate respiration and abolish the inhibitory effect of potassium on the glycolytic activity of bull spermatozoa. The effect of high potassium concentration and combinations of potassium and calcium on the ICF of ram spermatozoa has, therefore, also been investigated. Other factors such as osmotic pressure and buffer composition are known to influence the motility of ram spermatozoa (Blackshaw \& Emmens, 1951; Quinn, White \& Wirrick, 1966) and more critical studies are reported here using impedance change frequency (ICF) as a more objective criterion of the motility of spermatozoa in the CFDA.

\section{MATERIALS AND METHODS}

Ram semen was collected by electrical stimulation (Blackshaw, 1954) and kept at $30^{\circ} \mathrm{C}$ during transfer to the laboratory. The semen was placed in the dialysis sacs within $30 \mathrm{~min}$ of collection and the IGF/min was measured with an impedance bridge connected to a phase sensitive detector and a discriminator circuit to record impedance changes on a mechanical counter (Martin \& Wallace, 1965). The IGF was determined at 30-min intervals in a CFDA similar to that described by Dott \& Walton (1960) with a flow rate of $15 \mathrm{ml}$ of diluent/hr.

The composition of diluents used in Exp. 1 is shown in Table 1. The diluents were kept isotonic by adding appropriate amounts of glucose. In Exp. 2, the Krebs-Ringer-glucose was buffered to $\mathrm{pH} 7 \cdot 4$ with 50 mM-sodium phosphate (Boyd, 1966), 50 mm-tris-HCl or $50 \mathrm{~mm}$-barbital (veronal) (Burstone, 1962) and a comparison made with Krebs-Ringer-glucose containing $50 \mathrm{~mm}-$ trisodium citrate. The tonicity of the Krebs-Ringer-glucose buffered with 50 mM-sodium phosphate in Exp. 3 was adjusted to 167 and $617 \mathrm{~m}$-osmoles/1 by using $\mathrm{NaCl}$ concentrations of $37 \mathrm{~mm}$ and $245 \mathrm{~mm}$, respectively.

The diluent used in Exp. 4 consisted of $130 \mathrm{~mm}-\mathrm{NaCl}, 4 \mathrm{~mm}-\mathrm{MgCl}_{2}, 44$ mu-glucose to which was added $5 \mathrm{~mm}-\mathrm{KCl}$ or $1 \mathrm{~mm}-\mathrm{CaCl}_{2}$ or a combination of both; it was buffered with 50 mm-sodium phosphate.

The potassium concentration of the Krebs-Ringer-phosphate-glucose used in Exp. 4a (Text-fig. 1) was 0, 2.6, 38 and $51 \mathrm{~mm}$ and the sodium concentration $130,126,65$ and $43 \mathrm{~mm}$ respectively. The hypotonic diluents of Exp. 4b (Text-fig. 1) contained one tenth of the sodium and potassium concentrations of the Krebs-Ringer-phosphate-glucose.

The mean ICF/min over the 6-hr dialysis period was subjected to analysis of variance and the residual mean square used to derive the standard error of the difference between treatment means. Using the degrees of freedom associated with the error variance, $t$-test comparisons were made.

\section{RESULTS}

Experiment 1: Comparison of diluents of cation composition similar to male reproductive tract fluids

Ram semen was dialysed against diluents with cation compositions similar to those of Krebs-Ringer, rete testis fluid, epididymal and ejaculated seminal plasma, and ejaculated spermatozoa buffered to $\mathrm{pH} 7.4$ with 50 mm-sodium 


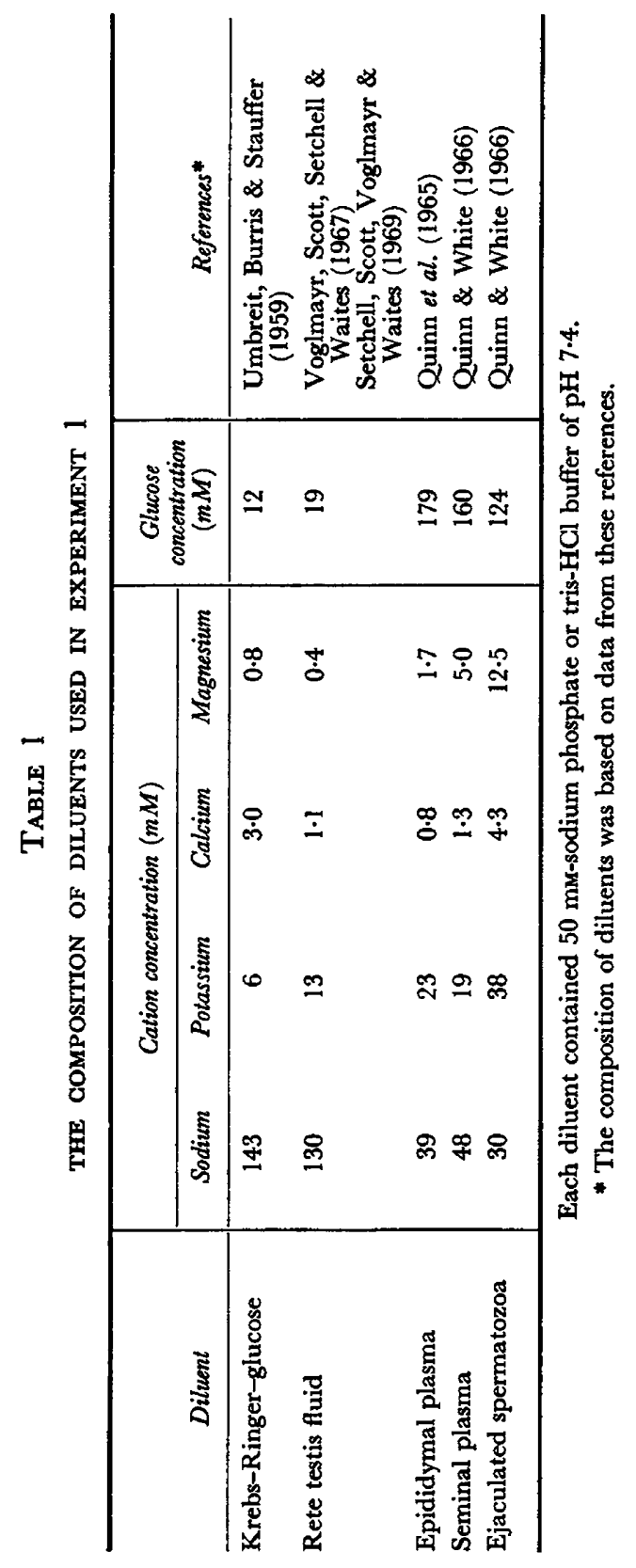


phosphate or $50 \mathrm{~mm}$-tris-HCl. The mean ICF/min during $6 \mathrm{hr}$ is shown in Table 2.

Diluents buffered with sodium phosphate maintained a high IGF during $6 \mathrm{hr}$. The mean ICF/min was significantly higher in the 'ejaculated spermatozoa'

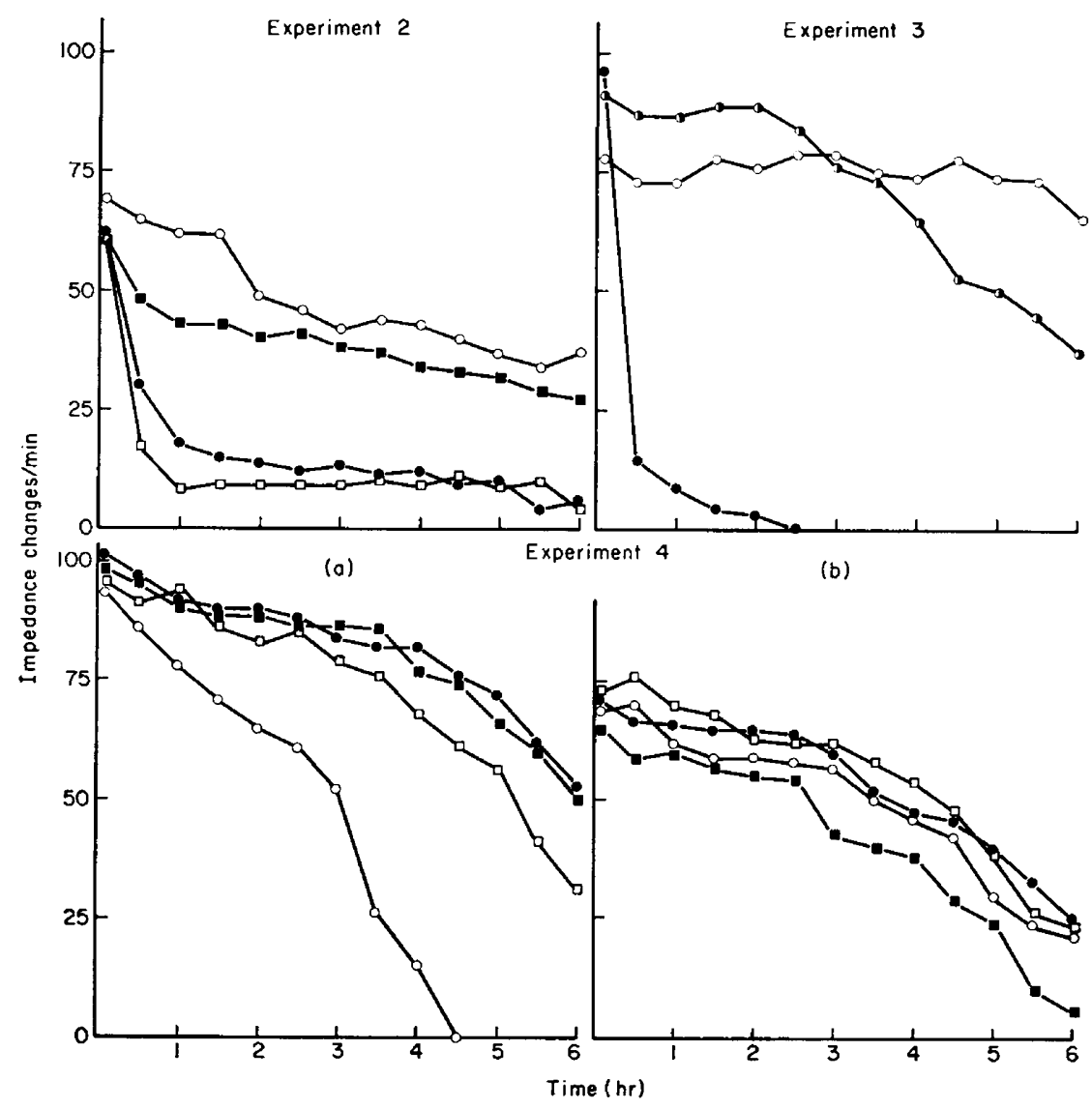

Text-Fig. 1. Exp. 2. ICF of ram spermatozoa in Ringer-glucose buffer with phosphate, 0 ; tris, ; veronal, $\square$; and citrate, $\square$. Mean of four replicates.

Exp. 3. ICF of ram spermatozoa in Ringer--phosphate-glucose isotonic, ; hypotonic, $O$; and hypertonic, Mean of three replicates.

Exp. 4. ICF of ram spermatozoa in Ringer-phosphate-glucose diluents of varying potassium and sodium composition. (a) Isotonic diluents: $\mathrm{No} \mathrm{K}^{+}, 130 \mathrm{~mm}-\mathrm{Na}^{+}, 0$; $2.6 \mathrm{~mm}-\mathrm{K}^{+}$and $126 \mathrm{mM}^{-\mathrm{Na}^{+}}$, ; $38 \mathrm{mM}-\mathrm{K}^{+}$and $65 \mathrm{~mm}-\mathrm{Na}^{+}, \square ; 51 \mathrm{~mm}-\mathrm{K}^{+}$and 43 mu-Na ${ }^{+}$, (b) (b) Hypotonic diluents: $\mathrm{No} \mathrm{K}^{+}, 13 \mathrm{~mm}-\mathrm{Na}^{+}, 0 ; 0.26 \mathrm{~mm}-\mathrm{K}^{+}$and $12.8 \mathrm{~mm}-$ $\mathrm{Na}^{+}, ; 3.8 \mathrm{~mm}-\mathrm{K}^{+}$and $6.5 \mathrm{~mm}-\mathrm{Na}^{+}, \square ; 5.1 \mathrm{~mm}-\mathrm{K}^{+}$and $4.3 \mathrm{~mm}-\mathrm{Na}^{+}, \boldsymbol{\square}$; Mean of four replicates.

diluent than in 'epididymal plasma' or 'rete testis fluid' diluents. When the diluents were buffered with tris-HCl, there was a rapid decrease in ICF during the 1 st $\mathrm{hr}$ in each case but on further dialysis, the IGF was highest in KrebsRinger and the 'ejaculated spermatozoa' diluent. No impedance changes were recorded after $4 \mathrm{hr}$ dialysis against 'rete testis fluid' diluent. 
Experiment 2: Effect of buffers

Since the ICF was greatly influenced by the buffer used in the previous experiment, the effects of four buffers used in diluents for ram semen was next investigated. Ram semen was dialysed for $6 \mathrm{hr}$ in the CFDA against KrebsRinger-glucose buffered with phosphate, tris, veronal or trisodium citrate. There was marked and rapid decline in the ICF during the lst hr in tris or veronal (mean IGF/min, 17 and 13 respectively) but little change in ICF with either buffer during the subsequent 5-hr dialysis (Text-fig. 1). Phosphate and citrate maintained a high ICF (mean ICF/min, 50 and 38 respectively) and both were significantly better than tris or veronal.

\section{TABle 2}

THE ICF OF RAM SEMEN DURING DIALYSIS AGAINST DILUENTS OF CATION GOMPOSITION SIMILAR TO MALE REPRODUCTIVE TRAGT FLUIDS

\begin{tabular}{l|cc}
\hline \multirow{1}{*}{\multicolumn{1}{c|}{ Diluent }} & \multicolumn{2}{|c}{ Mean ICF/min } \\
\cline { 2 - 3 } & Sodium phosphate & Tris- $\mathrm{HCl}$ \\
\hline Krebs - Ringer & 80 & $28 * *$ \\
Rete testis fluid & 74 & 19 \\
Epididymal plasma & 74 & 20 \\
Seminal plasma & 77 & 21 \\
Ejaculated spermatozoa & $87 *$ & $27 * *$ \\
S.E.M. & $5 \cdot 8$ & $2 \cdot 0$ \\
& & \\
\hline
\end{tabular}

$* P<0.05 ; * * P<0.01$, significantly different from rete testis fluid. S.E.M. represents standard error of mean.

Mean values are given (thirteen observations during $6 \mathrm{hr}$ dialysis) for four replicates in phosphate buffer and three replicates in tris-HCl buffer.

\section{Experiment 3: Effect of tonicity}

In the first experiment, the tonicity of the various diluents was kept constant by adding appropriate amounts of glucose. To investigate more systematically the effect of tonicity on ICF, ram semen was dialysed against Krebs-Ringerphosphate-glucose diluents of 167, 390 and 617 m-osmoles/l. Text-fig. 1 shows that dialysis against a hypertonic diluent caused an immediate decrease in ICF and no impedance changes could be detected after $2 \frac{1}{2} \mathrm{hr}$. There was no significant difference between the mean ICF of spermatozoa in the other diluents but after $6 \mathrm{hr}$, the ICF was highest in the hypotonic diluent.

\section{Experiment 4: Effect of calcium and potassium}

Of the diluents used in Exp. 1, Krebs-Ringer and the 'spermatozoa' diluents both contained relatively high concentrations of calcium. To check if this was responsible for maintaining a high ICF, ram semen was dialysed against Krebs-Ringer-phosphate-glucose containing 0, 2.5, 5 and $7 \cdot 5 \mathrm{~mm}^{-\mathrm{CaCl}_{2}}$.

Calcium concentrations of up to $5 \mathrm{~mm}$ were slightly beneficial, particularly during the first $4 \mathrm{hr}$ of dialysis. Further experiments showed that $2 \mathrm{~mm}$-calcium was also beneficial when the spermatozoa were dialysed against calcium-free 
hypotonic Krebs-Ringer-phosphate-glucose. Potassium ( $5 \mathrm{~mm}$ ) also increased the ICF (Table 3 ) in an isotonic diluent but exerted its effect independently of calcium $(1 \mathrm{~mm})$. Increasing the concentration of potassium up to $51 \mathrm{~mm}$, with a corresponding decrease in sodium to maintain a constant overall monovalent cation concentration, had a similar beneficial effect; when potassium was omitted from the isotonic dialysis medium, the ICF fell to zero after $5 \mathrm{hr}$ (Text-fig. 1a). However, in a hypotonic diluent, the ICF was maintained at a high level even in the absence of potassium (Text-fig. Ib).

TABLE 3

THE EFFECT OF GALCIUM AND POTASSIUM ON THE ICF OF RAM SPERMATOZOA

\begin{tabular}{|c|c|c|}
\hline Cation added & & Mean IGF/min \\
\hline $\begin{array}{c}5 \mathrm{~mm}-\mathrm{K}^{+} \\
1 \mathrm{~mm}-\mathrm{Ca}^{++} \\
5 \mathrm{~mm}-\mathrm{K}^{+}+1 \mathrm{mM}^{+} \mathrm{Ca}^{++}\end{array}$ & & $\begin{array}{l}30 \\
40 \\
37 \\
50\end{array}$ \\
\hline \multicolumn{3}{|c|}{ Analysis of variance } \\
\hline Source of variations & $d . f$. & Variance ratio \\
\hline $\begin{array}{l}\text { Between treatments } \\
\text { Potassium } \\
\text { Calcium } \\
\text { Interaction } \\
\text { Between replicates } \\
\text { Residual mean square }\end{array}$ & $\begin{array}{l}3 \\
\\
\\
1 \\
\\
2 \\
2\end{array}$ & $\begin{aligned} & \begin{array}{l}17.5^{* *} \\
8 \cdot 7 * \\
0.2\end{array} \\
14 \cdot 0 * * & \\
22 & \end{aligned}$ \\
\hline
\end{tabular}

$* P<0.05 ; \quad * * P<0.01$.

\section{DISCUSSION}

In the ram, changes in the inorganic cation composition of diluents reflecting that of fluids in which spermatozoa are transported through the male reproductive tract seem to have little influence on the ICF of the spermatozoa. However, a diluent with a cation composition similar to ejaculated spermatozoa maintained a higher IGF than did diluents simulating the cation concentration of epididymal and rete testis fluid and seminal plasma buffered with tris. The ability of ejaculated spermatozoa to transport cations against concentration gradients has been previously reported (Quinn \& White, 1967) and the presence of a sodium-potassium stimulated ATPase in spermatozoa is probably concerned with ion translocation (Quinn \& White, 1968). If the ionic composition of the dialysis medium is reflected in the spermatozoa as indicated in dilution studies (Quinn et al., 1966), then this would suggest that spermatozoa in vivo regulate their intracellular ionic composition from the less favourable extracellular plasma to that more conducive to motility.

Trisodium citrate proved as efficacious as phosphate buffer for ram spermatozoa in the GFDA. Gitric acid occurs in high concentration in ram semen 
(Mann, 1964) and is probably of importance in maintaining the $\mathrm{pH}$. At the relatively high concentration of $50 \mathrm{~mm}$, tris and veronal decreased the IGF of ram spermatozoa. An adverse effect of veronal on the motility of ram spermatozoa has been noted previously at a concentration of $33 \mathrm{~mm}$ (Quinn et al., 1966) and $20 \mathrm{~mm}$-veronal depresses metabolic activity more than the same concentration of tris (Wallace \& Wales, 1964).

It is generally believed that mammalian spermatozoa are more tolerant to hypertonic than to hypotonic conditions (see Mann, 1964). The present experiments show, however, that the ICF of ram semen dialysed against a diluent with a tonicity as low as $167 \mathrm{~m}$-osmoles/ 1 was comparable to Krebs-Ringer, whereas hypertonicity caused cessation of ICF. Quinn \& White (1969) have recently reported that ram spermatozoa are only adversely affected by rapid dilution in hypotonic diluents and slow exposure to the dialysis solution in the CFDA must enable ram spermatozoa to become acclimatized to hypotonic, but not to hypertonic media.

In studies concerned with the effects of inorganic ions on the motility of ejaculated spermatozoa, the semen has been washed or diluted and consequently the influence of the non-dialysable components in the seminal plasma is inevitably reduced. This should also be borne in mind when comparing the results obtained by motility scores on diluted semen and ICF measured in a GFDA. Thus, the motility and metabolism of ram spermatozoa are slightly depressed in media containing calcium (Lardy \& Phillips, 1943; Blackshaw, 1953; Wallace \& Wales, 1964) but in the GFDA, the inclusion of a small amount of calcium in the dialysis medium had a slightly beneficial effect on ICF.

We have confirmed that ram spermatozoa require low concentrations of potassium in isotonic dialysis media in order to maintain a high ICF (Dott \& White, 1964) but were unable to demonstrate such a requirement for potassium in hypotonic diluents. The highest concentration of potassium in our experiments (51 mM) did not depress the ICF. Since the molar ratio of $\mathrm{K}: \mathrm{Na}$ in this diluent was about 1 , it seems unlikely that this, by itself, is the explanation for the quiescent state of spermatozoa in the epididymis (Sørensen \& Andersen, 1956; Graves \& Salisbury, 1959).

\section{ACKNOWLEDGMENTS}

The authors are grateful to Professor G. W. Emmens for his interest and advice. The work has been aided by grants from the Ford Foundation, the Australian Wool Board and one of us (P.J.Q.) was supported by a Royal Agricultural Society (N.S.W.) Fellowship.

\section{REFERENCES}

Blackshaw, A. W. (1953) The effects of potassium and calcium salts on the motility of ram, rabbit and bull spermatozoa. F. Physiol., Lond. 120, 465.

Blackshaw, A. W. (1954) A bipolar electrode for the production of ejaculation in sheep. Aust. vet. $\mathcal{F}$. 30, 249.

Blackshaw, A. W. \& Emmens, C. W. (1951) The interaction of pH, osmotic pressure and electrolyte concentration on the motility of ram, bull and human spermatozoa. 7. Physiol., Lond. 114, 16.

Boyd, W. C. (1966) A nomogram for phosphate buffers. F. biol. Chem. 240, 4097.

Burstone, M. S. (1962) Enzyme histochemistry, p. 577. Academic Press, New York. 
CRABO, B. (1965) Studies on the composition of epididymal content in bulls and boars. Acta vet. scand. 6, Suppl. 5.

Crabo, B. \& Gustafsson, B. (1964) Distribution of sodium and potassium and its relation to sperm concentration in the epididymal plasma of the bull. $\mathcal{7}$. Reprod. Fert. 7, 337.

Gragle, R. G. \& Salisbury, G. W. (1959) Factors influencing metabolic activity of bull spermatozoa. 4. $\mathrm{pH}$, osmotic pressure and the cations sodium, potassium and calcium. F. Dairy Sci. 42, 1304.

Gragle, R. G., Salisbury, G. W. \& Muntz, T. H. (1958) Distribution of bulk and trace minerals in bull reproductive tract fluids and semen. F. Dairy Sci. 41, 1273.

DotT, H. M. \& WALton, A. (1960) Effects of dilution and washing on ram spermatozoa studied by a flow dialysis technique. 7. Reprod. Fert. 1, 350.

DotT, H. M. \& White, I. G. (1964) Effect of potassium on ram spermatozoa studied by a flow dialysis technique. 7. Reprod. Fert. 7, 127.

Graves, C. N. \& Salisbury, C. W. (1959) The production of epididymal like ejaculated bovine spermatozoa. J. Dairy Sci. 42, 932.

Lardy, H. A. \& Phillips, P. H. (1943) Effect of $\mathrm{pH}$ and certain electrolytes on the metabolism of ejaculated spermatozoa. Am. F. Physiol. 138, 741.

ManN, T. (1964) The biochemistry of semen and of the male reproductive tract, p. 342. Methuen, London.

Martin, I. C. A. \& Wallace, C. S. (1965) Impedance change frequency of diluted ram semen recorded on a digital scaler. F. Reprod. Fert. 10, 425.

Quins, P. J. \& White, I. G. (1966) Variation in semen cations and its relation to semen quality and method of collection. Fert. Steril. 17, 815.

Qunn, P. J. \& WhIte, I. G. (1967) Active cation transport by dog spermatozoa. Biochem. F. 104, 326.

QuinN, P. J. \& WhrTe, I. G. (1968) The activity and distribution of adenosinetriphosphatases in ram and bull spermatozoa. F. Reprod. Fert. 15, 449.

Quinn, P. J. \& White, I. G. (1969) Osmotic shock of ram spermatozoa. F. Reprod. Fert. 18, 375.

QuinN, P. J., WhITE, I. G. \& WIRRICK, B. R. (1965) Studies of the distribution of the major cations in semen and male accessory secretions. F. Reprod. Fert. 10, 379.

Quinn, P. J., White, I. G. \& WirRick, B. R. (1966) The effect of dilution on the concentration of sodium, potassium, calcium and magnesium in ram and bull spermatozoa. F. Reprod. Fert. 12, 131 .

SAlisBury, G. W. (1962) Ionic and osmotic conditions in relation to metabolic control. In: Spermatozoan Motility, p. 59. Ed. D. W. Bishop. Amer. Assoc. Adv. Sci., Washington, D.G.

Salisbury, G. W. \& CRagle, R. G. (1956) Freezing point depressions and mineral levels of fluids of the ruminant male reproductive tract. Proc. 3rd Int. Congr. Anim. Reprod., Cambridge, 1, 25.

Scott, T. W., Wales, R. G., Wallace, J. G. \& White, I. G. (1963) Composition of ram epididymal and testicular fluid and the biosynthesis of glycerylphosphorylcholine by the rabbit epididymis. 7. Reprod. Fert. 6, 49.

Setchell, B. P., Scott, T. W., Voglmayr, J. K. \& Wattes, G. M. H. (1969) Characteristics of testicular spermatozoa and the fluid which transports them into the epididymis. Biol. Reprod. Suppl. 1, 40.

Sørensen, E. \& Andersen, S. (1956) The influence of sodium and potassium ions upon the motility of sperm cells. Proc. 3rd Int. Congr. Anim. Reprod., Cambridge, 1, 45.

Umbreit, W. W., Burris, R. H. \& Stauffer, J. R. (1959) Manometric techniques in tissue metabolism. Burgess, Minneapolis.

Voglmayr, J. K., Scott, T. W., Setcheli, B. P. \& Waites, G. M. H. (1967) Metabolism of testicular spermatozoa and characteristics of testicular fluid collected from conscious rams. $\mathcal{F}$. Reprod. Fert. 14, 87.

Wales, R. G., Wallace, J. G. \& White, I. G. (1966) Composition of bull epididymal and testicular fluid. F. Reprod. Fert. 12, 139.

Wallace, J. C. \& Wales, R. G. (1964) Effect of ions on the metabolism of ejaculated and epididymal ram spermatozoa. F. Reprod. Fert. 8, 187.

White, I. G. (1953) Metabolic studies of washed and diluted ram and bull spermatozoa. Aust. 7. biol. Sci. 6, 706. 